\title{
A HUNGARIAN WAR HERO, FACTORY FOUNDER AND REFUGEE IN THE UNITED STATES - TIVADAR ROMBAUER
}

\author{
PÁL KOUDELA and JIN-IL YOO
}

Corresponding Author: Pál Koudela, PhD

Professor at Kodolanyi János University Collage

Department of International Relations, Székesfehérvár, Hungary

E-mail:pkoudela@yahoo.com or pkoudela@kodolanyi.hu

\author{
Co-Author: Jin-il Yoo, PhD
}

Central-Europe expert

Professor at the Hungarian Department at Hankuk University of Foreign Studies

Seoul, Korea

E-mail: yoojinil2002@hanmail.net

\begin{abstract}
Tivadar Rombauer was a less well-known, but important personality in Hungarian history. His entrepreneur career contains several business and technological innovations in iron industry, among which the foundation of the Metallurgical Factory in Ózd stands out. During the Revolution and War of Independence his role for managing arms supply nationwide is rarely emphasized by the regular commemorations of the most important historical momentum in Hungarian collective remembrance, although its relevance is undisputable. His Protestant Saxon origin interweaved with his patriotism resulted a typical Hungarian middle-class civic virtue, which never disappeared in later generations in the US, after his obligate immigration. In this study we scope on both the origins and influence of this valuesystem detailing Rombauer's life-span, complemented with the family roots and some descendants' fates.
\end{abstract}

Keywords: Hungarian Revolution, history of industry, Rombauer, genealogy, migration

In the following we are going to describe the life of Tivadar Rombauer in details, who established the first large-scale Iron Factory in Hungary at Ózd and later became the leader of arms supply for the Hungarian Revolution and War of Independence during 1848-49, but finally had to flee to America. His talent and role in Hungarian history is interesting and important in itself, but putting it into the context of his family's origin and the fate of overseas descendants gives more dimensions to the heritage and values he represented in Hungary. Such exemplary 
lifespans are carrying virtues never disappearing in forthcoming generations and show how modern western civic culture was built up from the smallest elements. Nevertheless, he was the founder of a family line with divergent branches in the US one and half centuries ago; Tivadar, his wife and their surviving children left Hungary between $1848-52$ for a new world.

\section{The Lutheran Family from Lőcse}

The Rombauer Family had German origins, but lived for centuries within the walls of Löcse in Upper Hungary, now Levoča in Slovakia. This small city, founded in the $12^{\text {th }}$ century, was one of those in the region with mostly Saxon inhabitants reserving their language, culture and integrity in a mainly Slovak environment in Hungary until the beginning of the $19^{\text {th }}$ century and even earned and kept a special legal position until the $18^{\text {th }}$ century. The family roots go back to the $17^{\text {th }}$ century, when Mathias Rombauer (1592-1640) was a city councilor (Demkó, 1897) ${ }^{1}$ They lived their peaceful civic life for generations, accumulating wealth, achieving higher and higher education, but among these silent builders of the society not any outstanding personality was born with the exception of a painter, János Rombauer. He was born in 1782 as a son of a wealthy joiner and studied artistry from Hungary, through Copenhagen to France, but still became an official painter for the Russian Tsar, Alexander I (Petrová-Pleskotová, 1968). In a late eclectic-style, inspired by Rembrandt and Rubens, he created portraits of Alexander I, Prince Czartoryski and many famous scientists and public figures, about fifty paintings remained of his oeuvre (Bayer, 1908). His generation was the first who moved out of Löcse: returning from Russia he settled down in Eperjes, but his brother, Gustave also moved to Pest in 1848 and even changed his name to the more Hungarian-sounding Romlaky (Divald, 1904). On another family branch a fourth cousin of János became clergyman, then livestock manager. Mátyás was born in Löcse in 1759 and was a man of means (Tóth, 1912, 670), having seven children of whom the oldest was János Tivadar Rombauer (Vass, 1996, 3-130).

\section{On the Way Becoming a Nationally Renowned Businessman}

Tivadar Rombauer was born in Löcse on January $23,1803,{ }^{2}$ in the Elhard family's still existing house at 22 Fötér. His mother was a daughter of the famous physicist and surgeon, János Elhard. It did not take a long time and the family had to move to Körmöcbánya (Kremnica) following his father's pursuit, where he became clergyman, then livestock manager. Later Tivadar's father worked at the Révay family's manor of Túróc County in Prékopa (Priekopa), but, due to the lack of 
schools there, the young Rombauer had been learning privately until he could finally enroll to the Lutheran Lyceum of Löcse in 1811. The father frequently changed jobs moving to new cities from time to time thus Tivadar finished his elementary school in Selmecbánya (today Banská Štiavnica in Slovakia) with the best results. Selmecbánya was probably the best decision for the teenage Tivadar to stay, because of its internationally famed Academy of Mining and Forestry. The College was established in 1763 by Marie Therese, it was the first of this kind in Europe. The institution, being Academy since 1770, became soon one of the most important scientific centers of technology. By the turn of the century significant educational and scientific life characterized it: Alessandro Volta made experiments there, innovations, such as the modern wire rope, was sooner introduced than in its place of origin in Clausthal (Faller, 1954). Selmecbánya was the second largest silver producer in the world, behind Argentina, that time and the third biggest city in Hungary. The Academy was supplemented with a faculty of forestry in 1808 and its educational system was so modern that in 1794 even the newly forming École Polytechnique of Paris esteemed it (Dudich, 1992). Tivadar enrolled in the Mining Academy in 1822, and started to study forestry too in the following year. He graduated in $1825^{3}$ and married her cousin, Bertha Rombauer on September 11, 1827.

His career started in 1825 at the iron foundry in Rohnic as an apprentice, but the following year he went to the Schönborn manor next to Munkács (now Мукачеве in Ukraine) to work for the industrial plants. The manor extended over two-thirds of Bereg County, $2351 \mathrm{~km}^{2}$ and 174 settlements belonged to it and the number of inhabitants exceeded the sixty thousand. Agriculture was neglected on this mainly wooded area, but, due to the sources of raw materials in the region, different industries, such as weaving, iron and chemicals were on their way to be developed. However, consumer markets were quite far and delayed development (Sas, 1955, 39-40). Rombauer, with his qualifications and diligence, soon became the overseer of the alum works in Pusztakerepes (name variant for Alsókerepec, today Нижній Коропець), next to Munkács and also participated in the development works of the metallurgical plants. A ten meter high forge was built under his direction in Selesztó between 1829 and 1832 and the foundry with its diverse casts became nationally renowned (Remport, 1995, 123). The management was largely satisfied with Rombauer's performance since he could save forty percent of the fuels and ten percent of the ores with his newly introduced technology and tools. As a consequence the factory realized 1750 quintals production growth until 1831. New foundries were built and new depositories were installed in Sátoraljaújhely, Kassa (today Košice in Slovakia) and (Buda)Pest. Rombauer also initiated the production of machine parts (Sas, 1955, 56-57) that time, and in 1832 he already wrote about artistic moldings in a submitting: the result was that one-fourth of the sales catalogue next year contained artistic casts in fact. 
Nothing could stop the progress: the factory received a gold medal (Nyárády, 1962, 133) in 1842 on the First National Industry Exhibition organized by Lajos Kossuth. Already in 1834 the management of the factory commissioned Rombauer by going to Gliwice, Poland, one of its foreign relations, to gain experiences, and in 1838 he was such a celebrity in the Monarchy that even Chancellor Metternich invited him for performing manorial services. However, Count Ferenc Schöborn retained him in Munkács by proposing higher position and salary. The offer was quite reasonable, because Rombauer boosted the factory's distribution to a large extent as in 1840 they had to refuse some orders from Pest on the grounds that only bigger casts are able to deliver, because of the huge demand.

In the 1930s Hungarian economy and industry received a boost by the increasing proportion of the arable land according to the inland water drainage and deforestation program. Increasing agricultural production influenced distance trade; wool became primary in export, but economy did not turn to monoculture yet. Accumulated capital was invested to build infrastructure: railway, banking, bridges and river regulation were all developing. Creating a national industry was first articulated by Lajos Kossuth, as an advocate of free trade, within the custom borders. He took a large part in the creation of the National Association of Industry (Iparegylet) and the Hungarian Trade Association (Magyar Kereskedelmi Társaság). After the First National Industry Exhibition in 1842 he ascertained that Hungary has no chance against the more developed Czech and Austrian industry thus protective tariffs are needed. Such questions were on the agenda in the Parliament during the decade. In the 1840 s food industry developed the fastest, steam-engines became commonplace nationwide. Iron industry production doubled during a couple of years, employment growth was 135\% (Kosáry, 2002).

\section{The Factory Founder}

In such a developing economic environment, in the following year after the successful participation in the exhibition in 1842, in which Kossuth specially praised the factory, Tivadar Rombauer nonetheless left his job in Munkács (that time he was the director of the factory) and became chief executive officer at the headquarters of the Coalition of Rima (Rimai Coalitio), one of the largest companies in Hungary, in Rimabrézó (today Rimavské Brezovo in Slovakia). In his new office, his tasks were larger scale: starting modernization by providing new iron ore licenses, for instance. He also proposed a plan for a new road, which was built for ten thousand forints. The investment was high-cost, but paid off soon since it helped to reduce transport costs with fifteen percent. He multiplied production with technical and organizational measures indicating a colossal profit growth for the company (Marton, 1906, 22). 
Iron industry leaders held a meeting in the Andrássy mansion in Hosszúrét (Krasznahorka-Hosszúrét, now Krásnohorská Dlhá Lúka close to Rožňava in Slovakia) on September 6,1843. This was already the second time to hasten progress in legislation: proposals for a mining act, founding a new Technical University and schools and developing infrastructure were discussed. Rombauer suggested a plan to build a new iron refinery and roller factory, larger and more modern than ever. Due to Széchenyi's and Kossuth's vision loads of rail were needed in Hungary for further development, but even the small metallurgical companies, which mainly characterized contemporary Hungarian economy, were unable for such production. For resolving this contradiction the government and the railway companies wanted to provide rails from abroad, from Wien in particular, but Rombauer had something else in his mind. He proposed the two largest companies in Hungary, the Coalition of Rima (Rimai Coalitio) and the Union of Murány (Murányi Unio) to be integrated to an even larger company (Jenei, 1980). Two important questions arose: whether the companies together have enough financial and human resources to apply the latest technology and whether the required technology is available in Austria to import or they should go further for it. For this reason the President and the CEO of the Rimai Coalitio, Pál SzathmáryKirály and Tivadar Rombauer were asked to travel to different Western-European countries for information and for probable negotiations. After their successful journey in England, Bohemia and Belgium the only remaining task was to find adequate coal sources, where the new factory could be installed nearby. After enumerating all possible places Ózd proved to be the most appropriate.

Abundant stocks of lignite were available there and experiments were carried out by Rombauer in the beginning in Germany, but later new furnaces were built in Hungary for testing the coal and to convince the skeptical land owners about future success (Óvári, 1967, 439). Ózd was a very small village that time, only 334 inhabitants were counted in the 1837 census by the conducting statistician Elek Fényes (Fényes, 1837). The Rimai Committee, led by Rombauer, was delegated to organize the new company and they developed the plan of the new iron factory by the May of 1845. The new Ironworks Association of Gömör (Gömöri Vasmüvelö Egyesület) was established under the technical management of Rombauer. The funds were 250 thousand forints and shared capital and entrepreneurs were both Hungarian, foreign subscription of shares were prohibited by its statutes to protect national interests. However, launching shares on the market was problematic, partly because of those land owners who were not wealthy enough to buy whole shares and partly because of political reasons. Count György Andrássy, a close friend of Széchenyi, with whom he travelled to England before the building of the Chain Bridge, was absent on negotiations, for instance. Since Rombauer belonged to the company of Kossuth - who had a decisive influence in factory building in Hungary at that time - Andrássy was afraid of being ignored 
in the management. Rombauer himself became a shareholder too, even if only with half a share.

Negotiations with the Central Hungarian Railways (Magyar Középpontú Vasúttársaság) ${ }^{4}$ started in 1845 , but soon failed without results and acquiring coal-beds came into focus. Rombauer himself has chosen proper sites and organized the building of factories and mines. It was a Herculean task to contract with the landowners one by one for the rights of transfer of coal..$^{5}$ Major excavations began in September 1846 with sixty miners. Foreign steam machines arrived to Vác on board via the Danube and from there by storage cart to Ózd. They were assembled by technical experts from Brno and England; such international coproduction was usual even in that period: a significant number of skilled workers came from abroad to Hungary in the $19^{\text {th }}$ century. At the beginning of the industrial revolution workers in Hungarian factories were mainly Polish, for example.

While the number of industrial worker population was 88,000 in 1805 , their volume increased to 125,000 by 1840 , but only one inhabitant became craftsman out of eighty in Hungary in contrast to the more developed Austria, where the rate was one craftsman out of 13-15 inhabitants. The 45,000 surplus of this period worked mainly in the large-scale industry. The number of smaller manufactories and larger factories in Hungary was only 528 altogether even in 1847, in which 23,400 workers were permanently employed, but even larger plants were rather small compared to the more developed countries. This was the beginning: the number of foreign skilled workers began to increase substantially in the following period, and the number of factory workers increased to fifteen times higher during the following forty years (Rézler, 1974).

The factory, however, had financial problems due to the unrealized contracts, and losses could have been complemented only by shareholders' further investments, namely by raising the price of shares, and as a result that profiles had to be replaced and rail production was delayed fifteen years. Nevertheless, Ózd had an outstanding position in Hungarian industrial history. Although the construction of the iron factory had not finished by the time, the rolling friction stir process was practiced first in Ózd in Hungary in 1847 - fifty years after England and twenty years after Western Europe. Tivadar Rombauer is usually considered to be the founder of the whole production by establishing the factory. His work gave an impetus to further progress in industrialization, extending to such details as the production of the first ninety three meters long and seventy meters wide rolling mill and building the officials' and workers' houses, supplemented with ornamental gardens next to each (Faller, 1943, 370). 


\section{Perseverance in the Hungarian Revolution}

The wave of revolution against feudal rule in the year of the Spring of Nations arrived in Hungary in March. The following one and a half years long war of independence determined the fate of industry too. Construction and production was ceased in Ózd at the outburst of the revolution in 1848 thus foreign workers returned to their homelands. Lajos Kossuth and Tivadar Rombauer had a close relationship since the Exhibition and Kossuth called Rombauer to be a staff member of the first independent government formed by him in 1848 April. Rombauer immediately left the Rimai Coalition and accepted to be the Head of Department of Industry in the Ministry of Agriculture, Industry and Trade in Pest, led by Gábor Klauzál (Bakó, 1942, 22), therefore, the whole national manufacturing and crafts industry was under his direction.

Being a politician of national importance his situation was rather difficult: he had to organize a mostly Austria-dependent national industry in a rather chaotic period. His very first action in May was to call the owners of mines, factories and industrial plants to Pest to hold a meeting. He wanted to import iron through Fiume and, at the same time, he had to deal with the production of saltpeter, gunpowder and cloth; fortunately wood, copper and tin was available in western Hungary. Opening a new sulfur mine in Kalinka and developing a new production method was also his merit, while the Austrian government has power enough to ban the import of sulfur from Sicily for preventing gunpowder production in Hungary. Because of the lack of arms production a large-scale production was also needed to be established in Hungary. The first factory was built in Pest next to the Rolling Mill in the Foundry and Machine Company Plant, these all were nationalized and later supplemented with smaller manufactories because of the constant sabotages.

Following Rombauer's proposal, the factory in Ózd was transformed for weapon production, and an engineer from Aachen was called to purchase equipment. Unfortunately he could not arrive because of border closures. Rombauer became the director of the nationalized armory in November, but also preserved his position as head of department. He had to adjust the factory for mass production thus recruited hundreds of workers from different factories, workshops and military troops. He developed regulations for workers, who were formally civilian, but were considered de facto deserters in case of leaving the factory without permission. At the same time, in November, the foundry stopped receiving proposals from Rombauer, a command from Kossuth ordered to produce cannon balls and grenades otherwise the factory would be confiscated. The forthcoming contract was signed by Lázár Mészáros, member of the government and by Vilmos Kubinyi, representative of the Coalition. Therefore, Rombauer was in a controversial position, since he became the director of the factory of which he re- 
mained one of its shareholders. Nevertheless, he was interested only in increasing productivity from both sides. He helped the factory to a loan and undertook the production of moldings prepared for barrels. ${ }^{6}$ However, the president of the association of the factory did nothing to change for weapon production, only admitted the loan. Despite such difficulties arms production was managed to be ensured in many different places: fifteen settlements only in upper Hungary; and supply was provided in the whole country. One of the small participating manufactures was the Kachelmann Foundry in Selmecbánya (Koudela, 2013).

The government had to move to Debrecen on January 1, 1849 and, as a consequence, the armory of Pest also escaped to Nagyvárad (Oradea), running away from Windischgrätz. The equipment was delivered on sleighs; it was 25-degree cold in the winter. Rombauer had to tackle plenty of difficulties: the evacuation of all machines failed, the supply Rombauer promised for workers could not be fulfilled and housing conditions in Nagyvárad (today Oradea in Romania) were much worse than those in Pest (Hegyesi, 1999). Despite these problems arms production started at the end of January and the impatient Kossuth and Rombauer could be satisfied with the castle furnished perfectly to an armory. There were still many disruptions: Rombauer had to displace all the smiths in February because of their disobedience and refill the missing jobs. Despite such circumstances he never had a say in the provisions of Kossuth and the factory remained operable. Rombauer sent one part of the factory of Pest to Ózd under the supervision of Tivadar Karafiáth, armory inspector. He wrote a report about leasing the factory in Ózd for arms production in the spring, but later decided to cancel it according to Karafiáth's report for lack of technical conditions of production there. ${ }^{7}$ Since they had no intention to manufacture arms, the inspector made the machines returned to Pest. Meanwhile, the Iron Company of Gömör, a main supplier, was threatened with bankruptcy, from which it escaped only in 1853 by joining in the former union of the Rimai Coalition and Murányi Union establishing the Rimamurány Iron Works Association (Jenei, 1980, 62).

\section{The Emigration - a New Life Established}

After the capitulation at Világos in 1848 Rombauer, among Kossuth and many others, had to flee disguised as a journeyman. He travelled to Hamburg through Austria dressed like a poor man, then followed his runaway to Belgium and to England. Becoming aware of the newly emerged fact that even smaller officials could not avoid prison he had no chance left to return to Hungary, finally he travelled to America. Many prominent Hungarian politicians fled to different European countries, such as Mednyánszky to Germany, Gorove to England or

Szemere and Teleki to France, but most of the Émigrés with a safe-conduct of 
Komárom looked for and found shelter in the New World (Albert, 1998, 66-96). Rombauer asked the help of Ferenc Pulszky and György Klapka to travel to the United States. Pulszky already helped him to reach London and then gave 480 pounds for a ticket to New York and for insurance, beneficiating his wife in case of a possible shipwreck. They were close friends and in Rombauer's farewell letter he also offered his help and expressed his desire: I wish "that next time our incorrectly applied idea of humanism... (wouldn't disclose others, and) not only Hungarian, but other nations would take part in it and share the obtained fruit."

As soon as he arrived in America Rombauer started to deal with mining and foundry (Forgáts, 1940, 181). He made a proposal for Washington in case of gold mining in California, but was refused. Later on he went on a tour to South America, where he met many Hungarian immigrants and gained experience. Returning from Argentina he settled down in a small village twenty five kilometers from Davenport, Iowa. He bought a land there to cultivate, but the farm was not prosperous thus the family soon moved to Davenport, the city full of French, German and English immigrants. During this period he also met Kossuth, with whom he discussed organizational questions, but politics increasingly played a smaller role in his life in America. In Davenport he became a co-editor at the German-language newspaper Der Demokrat, but only a few years had passed, and he died. He was only fifty-two years old when he passed away in 1855 (Vass, 1996, 3-130).

His wife, Bertha actively participated in the War of Independence as a nurse and followed her husband to America in 1850, since nothing else arose, she was busy to translate Hungarian poems to German (Rombauer, 1889). Tivadar and Bertha had eleven children of whom three died in the war: Richard was only eighteen when he fell in the Battle of Vízakna, Clara and Irma died during their persecution. The oldest daughter, Bertha, ${ }^{9}$ who was a schoolmistress, also followed her father to the USA and settled down in Davenport, but in the second year of her emigration, in the December of 1852 she died too. Her sister, Emma, married Gustavus A. Finkelnburg, a German immigrant, who became one of the prominent lawyers in St. Louis that time. Another child, Roland ${ }^{10}$ was a merchant and a Captain of the Cavalry during the Civil War and later became a member of the legislative body in Florida and Montana.

Ida, their sister, became also a schoolmistress and taught in a school founded by their mother until 1853, when she married Captain John Fiala, who was born in Temesvár (Timișoara) and later became Colonel under General Antal Vetter. Robert ${ }^{11}$, after finishing the Lutheran High School in Pozsony (Bratislava), moved to Vienna in 1848 and as a freshman in the Polytechnic joined the Legion of the Academy and later entered the army as a Lieutenant in artillery. After the fall of the Revolution he was enlisted in the Austrian Army as a private, but in 1850 he was freed with ransom and migrated to America with his mother. He also fought in the Civil War becoming Colonel of the $1^{\text {st }}$ U.S. Reserve Corps, 
Missouri Volunteers on the side of Lincoln. For his bravery, shown in defending the Pacific Railway, he was promoted to Brigadier Commander. Later he settled down in St. Louis becoming the president of the Board of Assessors St. Louis County and also a publisher of a newspaper and an accountant. He published a military treatise, titled The Contest (Rombauer, 1863) in 1863 and a mortality map of St. Louis in connection to the 1866 cholera (Rombauer, 1884). He wrote a study about education (Rombauer, 1913) and reminiscences about the events of 1861 (Rombauer, 1909). Robert also published books on nationalism and European state structure (Rombauer, 1915; Rombauer, 1916). He had a great cultural impact in St. Louis: the St. Louis Public Library was his idea, for instance, but he was also the president of the Board of Assessors and member of Board of Education (Vida, 190). Robert married Emilia Hogl, the widow of Count Theodor Dembiński ${ }^{12}$, nephew of the famous Polish General - both refugees due to their participation in the Hungarian Revolution.

Guido Rombauer ${ }^{13}$ studied as a craftsman at a machine manufacturer and also settled down in St. Louis. In 1861 he entered the Army as a sergeant at the Home Guard, and soon became a Major of the $1^{\text {st }}$ Illinois Light Artillery under General Washburn, commander of Tennessee. He directed two artillery battalions until he was prompted to the commander of the whole Artillery Division. Soon he was dismounted and next year married Emily Thomas, with whom he had five children. Getting to the Missouri Pacific Railroad he started as a director of the forwarding agents then superintendent of the Southwest Branch of the company. Following his entrepreneur spirit, he left his job and established his own minecoaling company, the Rombauer Coal Company in Novinger (Missouri). He was the head and the main shareholder at the same time (Pivány, 1913, 19).

Probably the most successful of Tivadar's children was Roderick. He studied at Dane Law School, Harvard and soon became a prominent member of St. Louis Society. Already at his studies he took an active part of the political campaign of John C. Fremont, later in Cambridge he supported the work of Prof. Emory Washburn, former governor of Massachusetts and at the outburst of the Civil War Roderick Rombauer had already proper investments and a large amount on his account, but for Lincoln's first call he enlisted as a volunteer in Missouri and soon became a captain (Rombauer, 1903, 22; [Roderick] Rombauer, 1915). After the Civil War he became the youngest judge in Missouri. As a consequence of a speech by him, the Bar Association of Metropolitan St. Louis was founded (Wilson, 1974, 4, 457-460). In 1875 the new constitution gave chance to create the St. Louis Court of Appeals, in which Roderick became a member and since 1884 his legislative career was unbroken for twelve years (Parrish, 2001, 291). His works on the theme were numerous. ${ }^{14}$

Roderick married Augusta Koerner on December 28, 1866 (Koerner, 1909, 451-452). Her father, Gustave Koerner was one of the co-founders of the Repub- 
lican Party and a close friend of Abraham Lincoln; he had an essential role in Lincoln's election for president in 1860 (Ecelbarger, 2008, 185). Some of his later descendants are also worth to mention: Roderick's second son, Edgar married Irma Starkloff, known as Irma Rombauer, the author of the Joy of Cooking (Mendelson, 1996). Roderick's third son was Alfred: his grandson, Koerner Rombauer is the founder of one of the largest vineyards in Napa Valley, California, where viticulture and oenology itself was founded by a Hungarian: Ágoston Haraszty establishing the Buena Vista Vinery between 1856 and 1869 (Sztáray, 1964; McGinty, 1998; Szente, 1978, 110-124).

\section{Conclusions}

As it is clear from the mentioned examples, the family found its place in America keeping the social position and values derived from the family's Protestant, Saxon roots in Löcse. Tivadar was a successful entrepreneur and his innovations largely contributed to a faster progress of Hungarian industrialization and he also proved his bravery during the War of Independence. However, after finding asylum overseas there was not much time and chances left and only his descendants could continue the silent, hard-working life, which Tivadar and his ancestors set as an example. Life spans and social environment are in close interrelation both in vertical and horizontal meaning. A career shows the features of a social group (Levi, 1989, 1325-1336), the middle strata in this case, but in two different ways: representing its actual social environment and its origins. Despite their presence in Hungarian society for centuries those few decades at the beginning of the $19^{\text {th }}$ century were worth more for developing a patriotic but also civic identity and culture and the Revolution had a special role in this process. A painter, a manufacturer, a judge, engineers and many other occupations: all typical middle class members, all Protestant and all with an indestructible will to create. Their values include frugality and diligence and the elements of the enhanced values of scholarship, rational systematization of government administration, and an increase in entrepreneurship ventures leading to a modern western value system - linked to Protestant origins (Bendix, 1977) - are also easy to find among them. Nevertheless, we shouldn't forget that from a recent geopolitical view these elements are part of the western civilization according to Huntington's interpretation and influence and this is clearly discoverable through the generations of this family. 


\section{References}

Albert, Gábor. A Kossuth-ellenes emigráció - Szemere Bertalan levelezése (1849-1851). In: Kortárs, Vol. 42, No. 6, 1998, pp. 66-96.

A Selmeczi M. K. Bányász- és Erdész-Akadémia évszázados fennállásának évkönyve 1770-1870. 1871. Selmecz.

Bayer, József. 1908. Újabb adatok Rombauerről In: Mủvészet, Vol. 7, No. 2, pp. 124-144.

Bendix, Reinhard. 1977. Max Weber: An Intellectual Portrait. Oakland.

Demkó, Kálmán. 1897. Löcse története. Lőcse: Reiss.

Divald, Kornél. 1904. Adatok Rombauer festö életéröl. In: Müvészet, Vol 3, No. 2, pp. 123-144.

Dudich, Endre. 1992. Les relations franco-hongroises dans le domaine de la géologie. Travaux du. Comité français d'Histoire de la Géologie. In: COFRHIGEO, 3ème série (tome 6), pp. 69-74.

Ecelbarger, Gary. 2008. The Great Comeback: How Abraham Lincoln Beat the Odds to Win the 1860 Republican Nomination. London: Macmillan.

Faller, Jenő. 1943. Régi kép és leírás Ózdról. In: Bányászati és Kohászati Lapok, No. 10.

Faller, Jenő. 1954. 1837-ben Selmecbányán készitették az első géppel vert sodronykötelet... In: MTA müszaki tud. oszt. közleményei, Vol. 8, Nos 1-4, 141-157.

Fényes, Elek. 1837. Magyarország mostani állapotja statisztikai és geográphiai tekintetben. Pest.

Forgáts, Béla. 1940. Rombauer Tivadar az 1848-49. évi szabadságharc fegyvergyári igazgatója és a Rimamurány-Salgótarjáni Vasmü Rt. alapitója. In: Bányászati és Kohászati Lapok, No. 73, pp. 177-182.

Hegyesi, Márton. 1999. Bihar vármegye 1848-1849-ben. Nagyvárad, pp. 88-94.

Jenei, Károly. 1980. Az alapitás elözményei. in: Az Ózdi Kohászati Üzemek története. Ed. Berend, T. Iván. Ózd, pp. 43-51.

Koerner, Gustave. 1909. Memoirs of Gustave Koerner, 1809-1896, Life-Sketches Written at the Suggestion of his Children. Vol. II. Torch Press, Cedar Rapids.

Kosáry, Domokos. 2002. Kossuth Lajos a reformkorban. Budapest: Osiris Kiadó.

Koudela, Pál. 2013. Selmecbánya helyi és regionális szerepe a magyar gazdaságban a 19-20. században. in: Közép-Európai Közlemények, Vol. 6, No. 22, pp. 186-194.

Levi, Giovanni. 1989. Les usages de la biographie. In: Annales: Économies, Sociétés, Civilisations, T. 44, No. 6, pp. 1325-1336.

Marton, János-Tetmajer, László. 1906. A Rimamurány-Salgótarjáni Vasmü Rt. fejlödésének története a XXV. közgyülés alkalmából. Budapest.

Mendelson, Anne. 1996. Stand Facing the Stove. New York: Henry Holt.

Nyárády, Gábor. 1962. Az elsö magyar iparmükiállitás. Budapest.

Óvári, Antal. 1967. Az ózdi vasmü alapitásának és elsö üzeméveinek vázlatos története. In: Kohászati Lapok, No. 10.

Parrish, William Earl-Foley, William E.-McCandless, Perry. 2001. A History of Missouri: 1860 to 1875. St. Louis: University of Missouri Press.

Petrová-Pleskotová, Anna. 1968. Die Entwicklungsaspekte des Schaffens Johann Rombauers. In: Časopis ARS, Vol. 2, No. 1, pp. 31-66.

Pivány, Eugene. 1913. Hungarians at the American Civil War. Cleveland.

Remport, Zoltán. 1995. Magyarország vaskohászata az ipari forradalom elöestéjén (1800-1850). Budapest.

Rézler, Gyula. 1974. A magyar nagyipari munkásság kialakulása 1867-1914. In: Magyar munkásszociográfiák 1888-1945. Ed. G. Litván. Budapest, pp. 15-26.

Riecke, Paul. 1900. Nachkommen von Dr. Johann Christoph Elhard. Brassó.

Rombauer, Bertha. 1889. Bunte Blätter. St. Louis: A. Wiebusch \& Son Prtg. Co. 
Rombauer, Robert. 1863. The Contest: A Military Treatise. St. Louis: A., Wiebusch.

Rombauer, Robert. 1884. Map of Part of the City of Saint Louis, Showing the Location of Deaths from Cholera in 1866: Prepared for $12^{\text {th }}$ Annual Meeting, A. P. H. A., Oct. 1884. St. Louis: A., Gast \& Co.

Rombauer, Robert. 1909. The Union Cause in St. Louis in 1861, an Historical Sketch, by Robert J. Rombauer. St. Louis: Press of Nixon-Jones prtg. Co.

Rombauer, Robert. 1913. A Study on Primary Education. St. Louis: Printed by R.J. Rombauer.

Rombauer, Robert. 1915. Peace Prospects (Carnegie visitors' reports) St. Louis: C., Hesse, Pr.

Rombauer, Robert. 1916. Elements of State Organization in Europe. St. Louis: C. Hesse, Pr.

Rombauer, Roderick. A Model Charge to a Jury: Delivered before the High Court of the Legion of Honor of St. Louis: in a Mock Trial for Breach of Promise of Marriage by Presiding Judge R.E. Rombauer in May 1888, St. Louis: Nixon-Jones Print. Co., 1911

Rombauer, Roderick. 1915. Ecce Heros. St. Louis.

Rombauer, Roderick 1865. Instructions to the Assessors of Districts in St. Louis County for the Assessment of State and County Taxes: Based on Date of First Monday in September, Fred. Kluender.

Rombauer, Roderick. 1869. Louis Post-Dipatch, May, 22.

Rombauer, Roderick. Missouri Appeal Reports, Vol. 16.

Rombauer, Roderick. 1869. St. Louis Republic, May, 22.

Rombauer, Roderick Emile. 1903. The History of a Life. Washington: Sas, Andor. 1955. Egy kárpáti latifundium a hübéri világ alkonyán: A munkácsi Schönborn-uradalom társadalmi és gazdasági viszonyai a XIX. század első felében. Bratislava: Csehszlovákiai Magyar Könyvkiadó.

Szente, Péter. 1978. Egy elfelejtett amerikás magyar: Hataszthy Ágoston. In: Századok, Vol. 112, No. 1, pp. 110-124.

Sztáray, Zoltán. 1964. Haraszthy Ágoston a kaliforniai szölőkultúra atyja. San Bernardino: Kossuth Foundation.

Tóth, Sándor. 1912. Sáros vármegye monográfiája. Vol. III. Budapest: http://mek.oszk. hu/12800/12885/pdf/12885_3_4.pdf (Retrieved: July 25, 2015)

Vass, Tibor. 1996. Rombauer Tivadar a gyáralapitó (1803-1855). Ózd: (Ózdi Honismereti Közlemények 12.)

Vida, István Kornél. The True Cause of Freedom: The Kossuth Emigration and the Hungarians' Participation in the American Civil War. PhD Dissertation.

Wilson, John. 1974. One Hundred Years of the St. Louis Bar. In: American Bar Association Journal, Vol. 60, No. 4, pp. 457-460.

\section{Notes}

1 His name was actually written like Rompauer in the 1667 and 1728 registers.

2 A Lőcsei Evangélikus Egyház lajstroma 1803 (Levoča Lutheran Church Register 1803), 9/11. no. document. Cited in: Riecke, Paul, Nachkommen von Dr. Johann Christoph Elhard, Brassó 1900.

3 A Selmeczi M. K. Bányász- és Erdész-Akadémia évszázados fennállásának évkönyve 17701870, Selmecz 1871, pp. 229-230.

4 MOL RMST-Okmánytár (Hungarian National Archive Rimamurány-Salgótarján Document Bank hereinafter referred only as HNA), Z 366-155.

5 MOL RMST-Okmánytár (HNA), Z 366-153/a. 
6 MOL RMST-Okmánytár (Hungarian National Archives, Documents of the Rimamurány-Salgótarján Ironworks), Z 366-6-197. - Pest, November 25, 1848. Rombauer Tivadar kötelezvénye: három hónapon belül az állami fegyvergyárban puskacső gyártása céljából két pár hengert öntet. (Promissory note of Theodore Rombauer: two pairs of cylinders to be cast in the state armory for gun barrel production within three months.)

7 MOL. RMST - Okmánytár (HNA), (Hungarian National Archives, Documents of the Rimamurány-Salgótarján Ironworks) Z 366-6-197. - April 7, 1849. Szerződéstervezet az állami fegyvergyár igazgatósága és a Gömöri Vasművelő Egyesület között az ózdi gyárnak puskacsövek gyártására való bérbevétele tárgyában. (Draft treaty between Board of Directors of the State Armory and Gömör Ironworkers' Association for the subject of leasing the Factory of Ózd for the purpose of producing gun barrels.)

8 OSZK Kézirattár (National Széchényi Library Archive), Rombauer Tivadar levele Pulszky Ferenchez 1849.

9 Born: 1828, Derizen (Munkács - Мукачеве)

10 Lived: 1837, Selesztó - 1898, Montana.

$11 * 1830$, Podhering (Munkács) - 1924, St. Louis

12 Written in Hungarian sources like Dembinszky

13 Lived: 1838, Munkács - 1912, St. Louis.

14 Rombauer, Roderick, St. Louis Republic, 1869, May 22, St. Louis Post-Dipatch 1869, May 22, Missouri Appeal Reports, Vol. 16-68, A model charge to a jury: Delivered before the High Court of the Legion of Honor of St. Louis : in a mock trial for breach of promise of marriage by presiding judge R.E. Rombauer in May 1888, St. Louis: Nixon-Jones Print. Co., 1911, and Instructions to the assessors of districts in St. Louis County for the assessment of state and county taxes: Based on date of first Monday in September, Fred. Kluender, 1865 